\title{
Fasya ve Faset Eklemi Arasındaki İlişki: Sistematik Derleme
}

\author{
Alper PERÇIN ${ }^{1 *}$ iD, Hasan Kerem ALPTEKIN ${ }^{2}$ iD \\ ${ }^{1}$ Iğdır Üniversitesi, Sağlık Bilimleri Fakültesi, Fizyoterapi ve Rehabilitasyon,76000, Iğdır, Türkiye \\ ${ }^{2}$ Bahçeşehir Üniversitesi, Sağlık Bilimleri Enstitüsü, Fizyoterapi ve Rehabilitasyon, İstanbul, Türkiye \\ *Sorumlu Yazar / Corresponding Author: Alper PERÇiN, e-mail: alperpercin@yahoo.com
}

\section{ÖZET}

Son yıllarda fasyanın fizyoterapi uygulamalarında hem değerlendirme hem de terapatik yaklaşımlar açısından ön plana çıkması, kas iskelet sistemi rahatsızlıklarını farklı bir bakış açısı ile değerlendirmek için bir fırsat ortaya çıkarmıştır. Bu çalışmada fasyanın faset eklemi ile anatomik bağlantıları, biyomekanik özellikleri, fasyaya terapatik yaklaşımlar uygulandığında nasıl bir etkileşim içinde oldukları ortaya konulmaya çalışılmıştır. Literatür taraması amacıyla Pubmed, Google Scholar ve ResearchGate veri tabanlarından yararlanıldı. Bu derleme çalışmasına 2013 ve 2017 yılları arasında yayınlanan dört adet tam metne sahip araştırma makalesi dahil edildi. Ayrıca; faset eklemi tutulumunun neden olduğu sırt ve boyun bölgesinde ortaya çıkan semptomların tedavisinde fasyal terapatik yöntemlerin etkileri araştırıldı. Anahtar kelime kombinasyonları "faset eklem" ve "fasya", "ve, veya" kullanılarak, "fizik tedavi", "rehabilitasyon" ve "fasyal tedavi yaklaşımları" gibi diğer kelimelerle birleştirildi. Dahil edilen çalışmaların kalite değerlendirmesi PEDro ölçeği kullanılarak yapıldı. Arama dört tam makalenin incelendiği 31 sonuç üretti. 367 katılımcıyı içeren dört randomize kontrollü araştırma, çalıșmamıza dahil edildi. Bu çalıșmaların metodolojik kalitesi incelendiğinde iki tanesi düşük, iki tanesi orta kalite olarak ortaya konuldu. Genel olarak fasyal terapatik yaklaşımların ağrı, spazm ve eklem hareket açıklığı (EHA) kısıtlılığı üzerinde etkili olduğu görüldü. $\mathrm{Bu}$ derleme çalışması, faset eklem disfonksiyonu nedeniyle ortaya çıkan ağrı, spazm, EHA kısıtlılığı gibi semptomlar için fasyal terapatik yaklaşımların etkinliği hakkında metodolojik bir yöntem izleyerek kanıta dayalı bilgiler sunmuştur. Faset eklem disfonksiyonunda fasyal terapatik yaklaşımların ağrı, spazm ve EHA kısıtlılığı semptomlarında önemli oranda iyileşme gösterdiğini ortaya koymuştur. Bu uygulamaların etkinliği altında yatan mekanizmaları anlamak için daha fazla araştırmaya ihtiyaç vardır.

Anahtar kelimeler: Ağrı, Dizabilite, Faset eklem, Fasya, Fizik Tedavi 


\title{
Relationship Between Fascia and Facet Joint: Systematic Review
}

\begin{abstract}
In recent years, the prominence of fascia in physiotherapy applications in terms of both evaluation and therapeutic approaches has created an opportunity to evaluate musculoskeletal disorders from a different perspective. In this study, it has been tried to reveal the anatomical connections of the fascia with the facet joint, its biomechanical properties, and how they interact when therapeutic approaches are applied to the fascia. Pubmed, Google Scholar and ResearchGate databases were used for literature review. Four full-text research articles published between 2013 and 2017 were included in this review. Also; The effects of facial therapeutic methods in the treatment of symptoms in the back and neck region caused by facet joint involvement were investigated. Keyword combinations "facet joint" and "fascia" were combined with other words such as "physical therapy", "rehabilitation" and "fascial therapy approaches" using "and, or". Quality assessment of the included studies was done using the PEDro scale. The search produced 31 results, of which four full articles were reviewed. Four randomized controlled trials involving 367 participants were included in our study. When the methodological quality of these studies was examined, two were revealed as low quality and two as medium quality. In general, facial therapeutic approaches were found to be effective on pain, spasm and limitation of joint range of motion (ROM). This review study presented evidence-based information on the effectiveness of facial therapeutic approaches for symptoms such as pain, spasm, and ROM limitation due to facet joint dysfunction, following a methodological method. It has been revealed that facial therapeutic approaches in facet joint dysfunction show significant improvement in the symptoms of pain, spasm and ROM limitation. More research is needed to understand the mechanisms underlying the effectiveness of these practices.
\end{abstract}

Key words: Ache, Disability, Facet joint, Fascia, Physical Therapy

\section{GíRiş}

Fasya, insan vücudunu kaplayan ve vücut yapılarının dayanıklılığını sağlamak için üç boyutlu bir ağ oluşturan bağ dokusunun yumuşak kısmını temsil eder (Findley ve ark., 2012). Bu üç boyutlu ağ bir bütün olup, vücudun her segmentinde mevcuttur. Kas ve kemik dokuları arasında bir kuvvet aktarıcısı görevi görür ve bu nedenle tüm hareketler için gereklidir (Paoletti, 2011). Kas-iskelet sistemine doğrudan etki eden düz kas hücreleriyle benzer kontraksiyona sahip olan miyofibroblastların, fasya içine gömülü olduğu ve bundan dolayı fasyal sistemdeki disfonksiyonların ağrı, spazm ve EHA kısıtlılığına yol açabileceği hipotezini ortaya çıkmaktadır (Schleip ve ark., 2008). Dahası çok sayıda mekanoreseptör propriyosepsiyonda önemli bir rol oynadığından, fasyalar önemli bir insan duyu organını temsil eder (Stecco ve ark., 2008). Travma, gerilme, aşırı yüklenme veya düzenli egzersiz yapılmamasından kaynaklanan iskemi ve hipoksi, fasyanın temel yapısında fizyolojik değişikliklere neden olabilir. $\mathrm{Bu}$ fizyolojik değişimler sonucu fasyanın 
elastikiyeti azalabilir ve bu durumda ağrı, spazm ve EHA kısıtlılığı ile sonuçlanabilir (Barnes, 1997). Torakolomber fasya veya torakodorsal fasya sırtın derin fasyasıdır. Gövdenin servikal, torasik ve lomber bölgelerinde bulunur ve erektör omurga kompleksini kapsar (Standring, 2004). Torasik bölgede vertebral kolonun ekstansör kasları için ince bir örtü oluşturur ve medial kısımda torasik vertebraların açılarına yakın olarak kostalara tutunur. Ayrıca karın duvarının düz kaslarına yanal olarak bağlanan güçlü bir aponevroz oluşturur (Vleeming ve ark., 2007). Torakolomber fasya, vertebralara geniş bir şekilde uzanması yoluyla supraspinöz ligamente, interspinöz ligamante ve faset eklemi kapsülüne bağlanır. İnterspinöz, supraspinöz, torakolomber ligament kompleksi omurgaya destek sağlar ve aynı zamanda üzerine binen yükü kas dokusundan faset eklem kapsülüne aktarır (Willard, 2007). Omurgayı anterior segmentte vertebra korpusları ile diskler, posterior segmentte ise nöral ark meydana getirmektedir. $\mathrm{Bu}$ nöral ark, arkus vertebra ile sağ ve sol olmak üzere iki tane faset ekleminden oluşur (Glover, 1977). Faset eklem, alt seviyedeki vertebranın zipoapofizyal superior'u ile üst seviyedeki vertebranın zigoapofizyal inferior' $u$ arasında oluşan plana tipinde, kapsüllü, diartrodial ve sinovyal eklemdir. Her faset eklemde dar bir eklem arası açıklığı vardır ve çok sınırlı kayma hareketi yapar. Faset ekleminde 1-2 $\mathrm{ml}$ arasında sıv1, sinoviyal membran, 2-4 $\mathrm{mm}$ kalınlığında hiyalin kartilaj ve yaklaşık $1 \mathrm{~mm}$ kalınlığında fibröz kapsül bulunur (Bogduk, 1997). Faset eklem kapsülü iki tabakadan oluşur, yoğun şekilde paralel kollajen liflerden oluşan bir dış tabaka ile düzensiz yerleşimli elastik liflerden oluşan bir iç tabakadan meydana gelir (Ashton ve ark., 1992). Faset eklemleri eklem boşluğuna uzanan eklem kapsülünün rudimenter invajinasyonları olan menisküslere sahiptir ve bu menisküsün fonksiyonu, yükleri daha büyük eklem yüzeyleri boyunca dağıtmak ve stabiliteye katkıda bulunmaktır (Schwarzer ve ark., 1994). Faset eklemler, dorsal raminin medial dalları tarafindan innerve edilir ve faset eklemlerde, serbest ve kapsüllenmiş sinir uçlarının yanı sıra P maddesi ve kalsitonin geni ile ilişkili peptid içeren sinir sonlanmaları bulunur (Falco ve ark., 2012). Servikal faset eklemlerde, C3-C4'den C8-T1'e kadar alt ve üst ramus dorsalisin medial dalı, C2-3 faset eklem ise C3 dorsal dalının iki farklı kısmından, atlanto oksipital ve atlanto aksiyel eklemler C1 ve $\mathrm{C} 2$ ventral dalları tarafindan innerve olur (Bogduk, 1982; Barop, 2017).

Fasya ve faset eklemin anatomik bağlantıları ve biyomekanik ilişkisi, faset eklemi disfonksiyonunda fasyal terapatik yaklaşımların etkili olabileceği hipotezini ortaya çıkarmıştır. Çalışmanın amacı, faset eklemi kaynaklı ağrı, spazm ve EHA kısıtlılığı 
yaşayan bireylerde fasyal tedavi yaklaşımlarının etkisini ortaya koymaktır.

\section{YÖNTEM}

Sistematik inceleme, PRISMA (Sistematik incelemeler ve Meta-Analizler için Tercih Edilen Raporlama Öğeleri) yönergelerine göre gerçekleştirildi. Dahil edilen çalışmaların kanıt düzeyi, Cochrane iş birliği tavsiyelerine dayalı oluşturuldu:

(a) Güçlü: birden fazla ( $\geq 2)$ yüksek kaliteli araştırmadan elde edilen tutarlı bulgular

(b) Orta: 2 veya daha fazla düşük kaliteli araştırma veya 1 yüksek kaliteli araştırmadan tutarlı sonuçlar

(c) Sınırlı: 1 düşük kaliteli araştırmadan elde edilen bulgular

(d) Çelişkili: birden fazla araştırmadan elde edilen tutars1z bulgular (Hutton ve ark., 2015).

Çalışma çerçevesinin belirlenmesi için metodolojik bir yol takip edildi. Bu yönteme göre katılımcılar, müdahale, karşılaştırma grupları, sonuçlar ve araştırma desenlerini oluşturulmaya çalışıldı (Brown, 2020).

\section{Veri tabanları Aracılığıyla Literatür} Araştırması

Literatür taraması, sırasıyla üç adet erişime açık veri tabanında faset eklem ve fasyal yaklaşımların ilişkisini ortaya koyan çeşitli çalışmaları belirlemek için yapıldı: Sırasıyla, PubMed, Google Scholar ve ResearchGate. Dikkate alınan çalışmalar 2013 ve 2017 yılı aralığında İngilizce dilinde yayımlanmıştır. Araştırma, aşağıdaki iki temel anahtar kelimenin kombinasyonu ile gerçekleştirildi: "faset eklem" ve "fasya". Bu iki anahtar kelimeler "ve, veya" kullanılarak, "fizik tedavi", "rehabilitasyon" ve "fasyal tedavi yaklaşımları" gibi diğer kelimelerle birleştirildi. Elektronik arama, elde edilen makalelerin referanslarının elle araştırılmasıyla tamamland1.

\section{Çalışmaya Dahil Edilme ve Dışlanma Kriterleri}

(a) Fasyal tedavi yaklaşımlarını içeren randomize kontrollü çalışmalar,

(b) Faset eklem dejenerasyonu kaynaklı sirt ve boyun ağrısı yaşayan bireylerin dahil olduğu randomize kontrollü çalışmalar olarak belirlendi.

Çalışmadan dışlanma kriterleri ise faset eklemi içerisine enjeksiyon yapılan müdahale grupları olarak belirlendi.

\section{Çalışma Seçimi}

İlk araştırmadan ve duplikasyonların kaldırılmasından sonra ortaya çıkan alıntıların başlıkları ve özetleri bağımsız olarak tarandı. İlgili çalışmaların özetleri gözden geçirilerek 
dahil edilme kriterlerini karşılayan çalışmaların tam metin makalelerine ulaşıldı.

\section{Metodolojik Kalitenin Değerlendirilmesi}

Yazarlarla ilgili bilgiler, dahil edilen katılımcıların özellikleri (yaş, cinsiyet, dahil edilme kriterleri, hastalığın şiddeti, örneklem büyüklüğü), müdahalelerin detayları (ev tabanlı ve denetimli, sıklık, yoğunluk ve tipi ve süresi), karşılaştırma grupları, değerlendirilen sonuçlar, takip süresi ve yan etkiler kaydedildi. Dahil edilen çalışmaların kalite değerlendirmesi, iyi bir geçerlilik ve güvenilirliğe sahip olduğu gösterilen PEDro ölçeği kullanılarak yapıldı (Maher ve ark., 2003).

\section{BULGULAR}

Servikal ve torakal bölgede faset eklem disfonksiyonu sebebiyle ağrı, spazm ve EHA k1sıtlılığı yaşayan bireylerde, fasyal terapatik yaklaşımların uygulandığ çalışmalara dahil edilen bireyler çalışmanın popülasyonunu oluşturuldu. Fasyal terapatik yaklaşımlar konvansiyonel fizik tedavi yöntemleri ile tedavinin etkinliği ve semptomların azalması açısından karşılaştırıldı. Çalışma dizaynının belirlenmesinde metodolojik yöntem aşağıdaki tabloda gösterildi (Tablo 1).

Tablo 1: Çalışma Dizaynı Belirlenmesinde PICOS Yöntemi

\begin{tabular}{|l|l|l|}
\hline P & Popülasyon & $\begin{array}{l}\text { Servikal ve torakal bölgede faset eklem disfonksiyonu ağrı, spazm ve EHA } \\
\text { kisıtlılığı yaşayan bireylerde, faset eklem tutulumu sebebiyle fasyal tedavi } \\
\text { alan bireyler }\end{array}$ \\
\hline I & Müdahale & $\begin{array}{l}\text { Fasyal Tetik Nokta Tedavisi, Fasyal Relaksasyon, Fasyal Manipülasyon } \\
\text { Yöntemleri, Fasyal Kuru Ĭgneleme, Fasyal Elektroakupunktur }\end{array}$ \\
\hline C & Karşılaştırma Grupları & Klasik fizik tedavi programı uygulanan bireyler \\
\hline O & Sonuçlar & Ağrı, Spazm, EHA \\
\hline S & Çalışma Dizaynı & Randomize Kontrollü Çalışmalar \\
\hline
\end{tabular}

Çalıșmanın akıș diyagramı PRISMA tablosunda gösterildi (Tablo 2). İlk veritabanı aramasında 31 makale bulundu. Duplikasyonlar kaldırıldıktan sonra 12 makale kaldı. Başlıklar ve özetler tarandıktan sonra uygunluk açısından 7 makale kaldı. $\mathrm{Bu}$ çalışmalardan fasyal 
terapatik yöntemlerin dışında başka fiziksel tedavi yöntemlerinin ön plana çıkarıldığı çalışmalar çıkarıldı. Geriye kalan 4 makalede, her iki cinsiyetten, servikal ve torakal omurga segmentlerinde faset eklem tutulumu olan toplam 367 kişi çalışmaya dahil edildi.

Tablo 2: Çalışmanın Akış Tablosu (PRISMA)
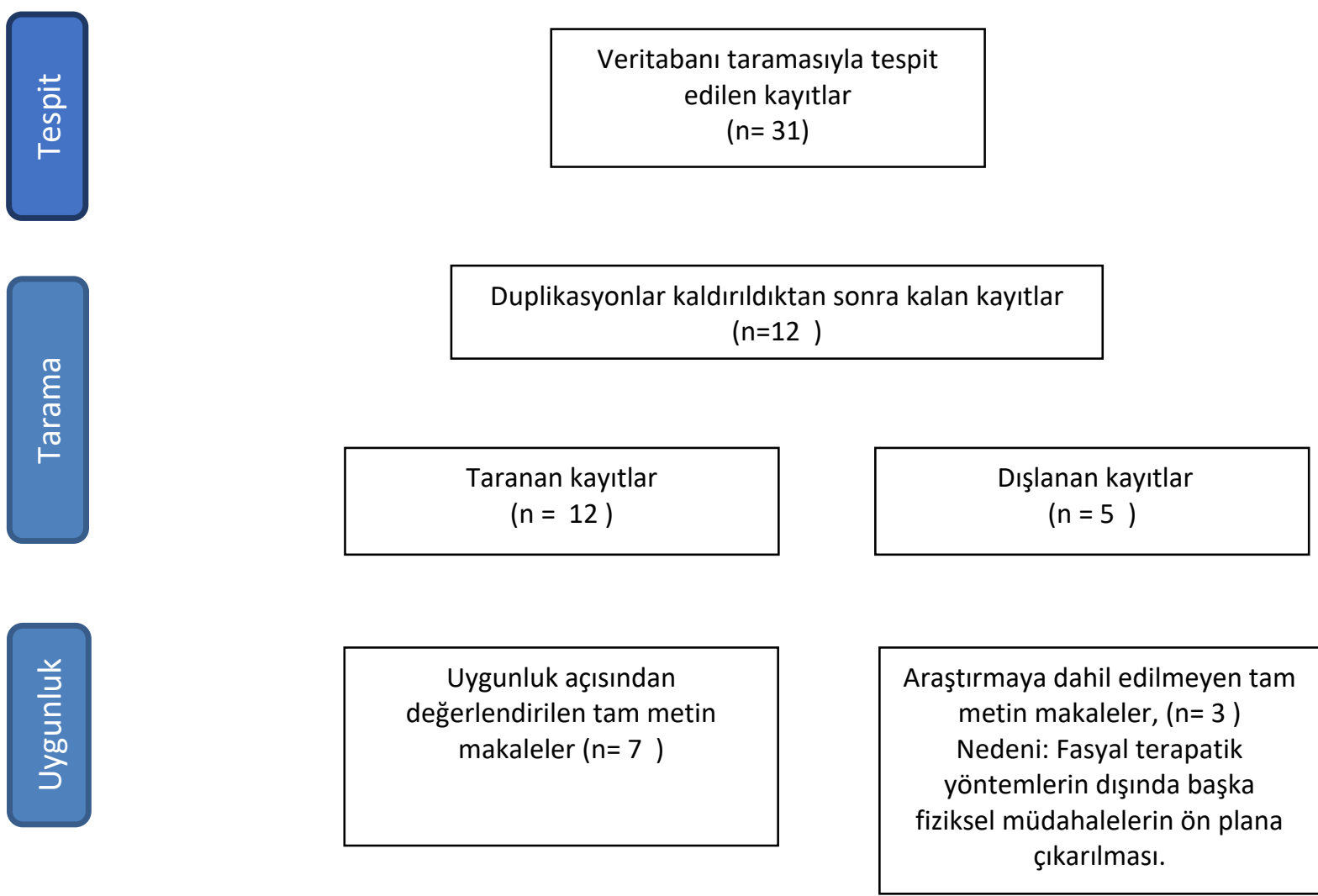

崖

Nicel (kantitatif) senteze (metaanaliz) dahil edilen çalışmalar $(n=4)$ 
Tablo 3: Dahil Edilen Çalışmaların Özellikleri, Sonuç Ölçüleri ve Sonuçları

\begin{tabular}{|c|c|c|c|}
\hline Çalışma & Popülasyon & Değerlendirme & Sonuçlar \\
\hline $\begin{array}{c}\text { Shanmugan } \\
\text { ve ark. (2017) }\end{array}$ & $\begin{array}{l}\text { Servikal Faset } \\
\text { Tutulum }\end{array}$ & $\begin{array}{c}\text { Ağrı (VAS) ve } \\
\text { EHA }\end{array}$ & $\begin{array}{l}\text { VAS (0-100mm): Başlangıç=73.47 } \\
24 \text { Saat Sonra: } 5.85 \\
1 \text { Hafta Sonra: } 2.12 \\
\text { Servikal EHA(Derece), Sagital Düzlem } \\
\text { (Flek.-Ekst.): Başlangiç } 30.38^{\circ} \\
24 \text { Saat Sonra: } 115.04^{\circ} \\
1 \text { Hafta Sonra: } 122^{\circ} \\
\text { Frontal Düzlem (Lateral Flek.) Başlangıç: } \\
13.76^{\circ} \\
24 \text { Saat Sonra: } 117.42^{\circ} \\
1 \text { Hafta Sonra: } 125^{\circ} \\
\text { Transvers Düzlem (Sağ-Sol Rotasyon): } \\
\text { Başlangıç: } 15.42^{\circ} \\
\text { 24 Saat Sonra: } 107.66^{\circ} \\
1 \text { Hafta Sonra: } 115^{\circ}\end{array}$ \\
\hline $\begin{array}{l}\text { Ye ve ark. } \\
(2013)\end{array}$ & $\begin{array}{l}\text { Torakal Faset } \\
\text { Tutulum }\end{array}$ & $\begin{array}{c}\text { Ağrı (VAS), PRI, } \\
\text { PPI }\end{array}$ & $\begin{array}{l}\text { Müdahale Grubu (A) Kontrol Grubu (B) } \\
\text { PRI: } 4.00+/-0.97(\mathrm{~A}), 5.44+/-1.16 \text { (B) } \\
\text { VAS: } 3.29+/-0.72(\mathrm{~A}), 3.87+/-0.81 \text { (B) } \\
\text { PPI: } 1.07+/-0.74(\mathrm{~A}), 1.64+/-0.90 \text { (B) }\end{array}$ \\
\hline $\begin{array}{l}\text { Zhou ve ark. } \\
\text { (2016) }\end{array}$ & $\begin{array}{l}\text { Torakal Faset } \\
\text { Tutulum }\end{array}$ & $\begin{array}{l}\text { Ağrı (VAS), Lokal } \\
\text { Spazm Skoru }\end{array}$ & $\begin{array}{l}\text { VAS (Müdahale Grubu): } \\
\text { Tedavi Öncesi: } 3.21 \pm 0.44 \\
\text { Tedavi Sonrasi: } 1.22 \pm 0.34 \\
\text { Lokal Spazm Skoru } \\
\text { Tedavi Öncesi: } 2.79 \pm 0.34 \\
\text { Tedavi Sonrasi: } 2.02 \pm 1.76\end{array}$ \\
\hline $\begin{array}{l}\text { Li ve ark. } \\
\text { (2013) }\end{array}$ & $\begin{array}{l}\text { Torakal Faset } \\
\text { Tutulum }\end{array}$ & $\begin{array}{l}\text { Ağrı (VAS) ve } \\
\text { Fiziksel Semptom } \\
\text { Skoru }\end{array}$ & $\begin{array}{l}\text { VAS Tuina Grup: } \\
\text { Tedavi Öncesi: } 6.34 \pm 1.05 \\
\text { Tedavi Sonras1: } 1.01 \pm 1.26 \\
\text { EA Grup: } \\
\text { Tedavi Öncesi: } 6.28 \pm 1.73 \\
\text { Tedavi Sonras1: } 2.02 \pm 1.76 \\
\text { Fiziksel Semptom Skoru Tuina Grup: } \\
\text { Tedavi Öncesi: } 5.7 \pm 2.6 \\
\text { Tedavi Sonras1: } 0.8 \pm 1.0 \\
\text { EA Grup: } \\
\text { Tedavi Öncesi: } 5.2 \pm 2.9 \\
\text { Tedavi Sonrasi: } 1.1 \pm 0.9\end{array}$ \\
\hline
\end{tabular}

(VAS: Vizüel Analog Skala, EHA: Eklem Hareket Açıklığı, Flek: Fleksiyon Açısı, Ekst: Ekstansiyon açısı, PRI: Ağrı puanlama skalası, PPI: Mevcut ağrı yoğunluğu, EA: Elektroakupunktur) 
Shanmugam ve ark.'nın yaptığı çalışmada, akut faset eklem disfonksiyonu görülen hastalarda servikal paraspinal kaslara kuru iğneleme uygulaması yapıldı ve toplam 21 hasta (13 Erkek, 8 Kadın) 12-15 dakika süreyle tek seans tedavi edildi (Tablo 3). Tedavi sonras1, 24 saat ve bir hafta sonra takip boyun ağrısını ve servikal omurganın hareket açıklığını değerlendirmek için Görsel Analog Skala $(0-100 \mathrm{~mm})$ ve gonyometre kullanıldı. Elde edilen verileri karşılaştırmak ortalama ve standart sapma kullanıldı. Uygulamadan hemen sonra ağrı skorunun (VAS) azaldığı ve servikal omurga hareket açıklığının 24 saat ve 1 haftalık takipte iyileştiği gösterildi. Servikal paraspinal kaslara kuru iğneleme uygulaması sonrası, ortalama ağrı skoru, başlangıç ağrısına oranla vizüel analog skalasına (VAS) göre olan 73.5 mm'den $(\mathrm{SD}=6.23) 18.8$ mm'ye $(\mathrm{SD}=5.07)$ düştü. Benzer şekilde, sagital $\left(95.33^{\circ} \pm 13.07^{\circ}\right)$, frontal $\left(91.90^{\circ} \pm 10.18^{\circ}\right)$ ve enine düzlemlerde $\left(88.28^{\circ} \pm 9.90^{\circ}\right)$ müdahale sonrası servikal omurga eklem hareket açıklığında da belirgin bir gelişme gösterdi. Bir haftalık takip sonrası ağrı (VAS: $2.12 \mathrm{~mm}$ ) ve servikal omurga

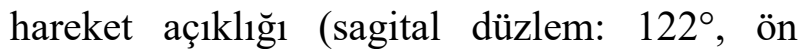
düzlem: $125^{\circ}$, enine düzlem: $115^{\circ}$ ) takip skorları, ağrı ve eklem hareket açıklığında tam iyileşmeyi gösterdi (Shanmugan ve ark., 2017).

Ye ve ark.'nın yaptığı çalışmada, elektroakupunktur tedavisi ile torakal manipülasyonun beraber uygulandığı ve yalnızca torakal manipülasyonun uygulandığı torasik faset eklem disfonksiyonlu bireylerde müdahalenin etkinlik farkını karşılaştırmak amaçland1. 160 katılımcı, her birinde 80 katılımcı olacak şekilde elektro-akupunktur ile manipülasyon uygulama grubuna (grup A) ve yalnızca manipülasyon uygulama grubuna (grup B) randomize edildi. A grubunda, torakal bölgede Ashi noktaları ve ağrılı bölgelere bilateral üç çift Jiaji noktaları seçildi. Ashi noktalarında dikey ponksiyon kullanıldı, Jiaji'de oblik ponksiyon kullanıldı ve 20 dakika boyunca elektrik stimülasyonu bağlandı, ayrıca faset eklem disfonksiyonunun görüldüğü vertebral segmentte manipülasyon uygulandı. B grubunda, etkilenen bölgelere yalnızca manipülasyon uygulandı. Elekto-akupunktur her gün uygulanırken, manipülasyon her 10 günde bir uygulandı. Hastaların tedavi öncesi ve sonrası ağrı puanlama skalası (PRI) skoru, görsel ağrı skalası (VAS) skoru ve mevcut ağr1 yoğunluğu (PPI) skoru hesaplandı ve iki grup arasında karşılaştırıldı. Bulgular karşılaştırıldığında tedavi sonrası PRI, VAS ve PPI skorlarının tümünün iki grupta da önemli ölçüde iyileştiği gözlendi (tümü $\mathrm{P}<0.05$ ) ancak burada A grubundaki sonuçların B grubundan daha iyi sonuçlar verdiği gözlendi (PRI: 4.00 +/- 0.97 vs 5,44 +/- 1,16, VAS: 3,29 +/- 0,72 vs 3,87 +/- 0,81, ÜFE: $1,07+/-0,74$ vs 1,64 +/0,90, tümü $\mathrm{P}<0.05$ ). Çalışmanın sonucunda elektroakupunktur ve manipülasyonun beraber 
uygulamasının, yalnızca manipülasyon uygulamasına kıyasla torasik faset eklem tutulumunda üstün etkinlik sağladığı görüldü. Kombine tedavinin, torakal faset eklem tutulumunun semptomlarını hafiflettiği ve disfonksiyona bağlı semptomların şiddetini azalttığını ortaya koydu (Ye ve ark., 2013).

Zhou ve ark.'nın yapmıș olduğu çalışmada, torakal faset eklem tutulumunda Jiaji noktalarına akupunktur uygulaması ve tuina manipülasyonunun klinik etkileri gözlemlendi. Toplam 106 hasta, sayı tablosuna göre bir gözlem grubu ve bir kontrol grubuna ayrıld1. Kontrol grubundaki hastalar sadece tuina manipülasyonu ile tedavi edilirken, müdahale grubundakiler tuina manipülasyonundan önce Jiaji (EX-B2) noktalarına akupunktur uygulaması ile tedavi edildi. Her iki gruptaki hastalar günde bir kez tedavi programına alındı. 3 seanstan sonra semptomlarda belirgin ve anlamlı bir iyileşme olup olmadığ 1 değerlendirildi. Kombine tedavi uygulanan müdahale grubunda tedavi öncesi VAS skoru $3.21 \pm 0.44$ iken tedavi sonrası $1.22 \pm 0.34$ olarak bulundu. Lokal kas spazm skoru tedavi öncesi $2.79 \pm 0.34$ iken tedavi sonrası $2.02 \pm 1.76$ olarak bulundu. Tedaviden sonra, her iki grupta da 8 belirti ve semptom skorunda grup içi istatistiksel farklılıklar olduğu görüldü $(\mathrm{P}<0.01)$. Müdahale grubunun genel iyileşme oran $1 \% 50,9$, kontrol grubunda ise $\% 26.4$ olarak bulundu ve iki grup arasında istatistiksel anlamlı bir fark vardı $(\mathrm{P}<0.05)$. Çalışmanın sonucunda torasik faset eklem tutulumu tedavisinde akupunktur ve tuina manipülasyonunun beraber uygulandığında, torakal omurgaların biyomekanik dengesini eski haline getirebildiği, birleşik etkiyi tamamen maksimize edebildiği ve klinik semptomları önemli ölçüde iyileştirebildiği gözlendi (Zhou ve ark, 2016).

Li ve ark.'nın yapmış olduğu çalışmada, faset eklem disfonksiyonunda tuina manipülasyonu ve elektro-akupunktur uygulamasının faset eklem disfonksiyonuna bağlı semptomlara etkisi gözlemlendi. 80 hasta, her birinde 40 hasta olmak üzere bir tuina manipülasyon grubu ve bir elektro-akupunktur grubu olarak randomize edildi. Bir gruba yalnızca tuina manipülasyonları ve diğer gruba sadece elektro-akupunktur uygulaması yapıldı. Görsel analog skala (VAS), semptomlar ve fiziksel belirtiler sirasıyla 5 tedavi seansından sonra değerlendirildi ve semptom skorları iki grup arasında karşılaştırıldı. 5 tedavi seansından sonra, iyileşme ve belirgin etkili oran manipülasyon grubunda \%91.9'a karşıllı elektro-akupunktur grubunda \%68.4'tü ve fark istatistiksel olarak anlamlıydı $(\mathrm{P}<0.05)$. VAS skoru Tuina grubunda tedavi öncesi $6.34 \pm 1.05$ iken tedavi sonrası $1.01 \pm 1.26$ bulundu. Elektroakupunktur grubunda ise VAS skoru tedavi öncesi $6.28 \pm 1.73$ iken tedavi sonras1 $2.02 \pm 1.76$ olarak bulundu. Fiziksel Semptom 
Skoru Tuina grubunda tedavi öncesi $5.7 \pm 2.6$ iken tedavi sonrası $0.8 \pm 1.0$ olarak bulundu. Elektroakupunktur grubunda fiziksel semptom skoru tedavi öncesi $5.2 \pm 2.9$ iken tedavi sonrası $1.1 \pm 0.9$ olarak bulundu. Tedaviden sonra her iki grupta da VAS skorları ve fiziksel semptom skorları önemli ölçüde azaldı $(\mathrm{P}<0.01)$ ancak tuina manipülasyon grubundaki semptomlarda daha anlamlı bir azalma gözlemlendi $(\mathrm{P}<0.01)$. Çalışmanın sonucunda torakal faset eklem disfonksiyonu tedavisinde elektro-akupunktur ile karşılaştırıldığında manipülasyonun daha etkili ve belirgin analjezik etkiye sahip olduğu anlaşıldı (Li ve ark., 2013).
Yanlılık riski değerlendirmesinde dahil edilme kriterleri ve kaynak, rastgele dağılım, gizli dağılım, başlangıçtaki karşılaştırılabilirlik, körleştirilmiş olgular, körleştirilmiş terapistler, körleştirilmiş değerlendiriciler, sonuçlar, tedavi amacına yönelik analiz, gruplar arası karşılaştırmalar, ortalama ve değişkenlik verileri maddelerinin yer aldığ1 PEDro ölçeği ile değerlendirildi ve 4 ile 7 arasında değişen randomize kontrollü çalışmaların ortalama puanı 5,75 puan olarak hesaplandı. En yaygın sinırlamalar, terapist ve katılımcı körleme eksikliği, değerlendirici körleme eksikliği olarak görüldü (Tablo 4).

Tablo 4: Yanlılık (BIAS) Riski: PEDro Skalası Skoru

\begin{tabular}{|l|c|c|c|c|c|c|c|c|c|c|c|}
\hline \multicolumn{1}{|c|}{ Çalışma } & 2 & 3 & 4 & 5 & 6 & 7 & 8 & 9 & 10 & 11 & Toplam \\
\hline Shanmugam ve ark (2017). & 0 & 0 & 1 & 0 & 0 & 0 & 1 & 1 & 0 & 1 & 4 \\
\hline Ye ve ark (2013). & 0 & 1 & 0 & 0 & 0 & 0 & 1 & 1 & 1 & 1 & 5 \\
\hline Zhou ve ark (2016). & 1 & 1 & 1 & 0 & 0 & 0 & 1 & 1 & 1 & 1 & 7 \\
\hline Li ve ark (2013). & 1 & 1 & 1 & 0 & 0 & 0 & 1 & 1 & 1 & 1 & 7 \\
\hline
\end{tabular}

\section{TARTIŞMA}

$\mathrm{Bu}$ sistematik derleme çalışmasının amacı, faset eklem disfonksiyonunda fasyal terapatik yaklaşımların ağrı, spazm ve EHA kısıtlılığı gibi yaygın semptomlar üzerindeki etkisini belirlemektir. Dört çalışmadan elde edilen veriler bu çalışmada değerlendirilmiştir.

Faset eklemi simetrisi ve doğru pozisyonu, sağlıklı bir disk fonksiyonu ve özellikle fleksiyon sırasında anormal yüklerden korunmak için temel gereksinim gibi görünmektedir (Fujiwara ve ark., 2000). Faset eklemin dejenerasyonu veya kötü pozisyonu, omurganın kas-iskelet yapıları içindeki mekanik yüklenmesini aşırı artırabilir, nosiseptörlerin irritabilitesini artırabilir ve derin paraspinal servikal ve torakal kasların fonksiyonlarını engelleyebilir (Hestbaek ve ark., 2009). Faset eklem disfonksiyonunda gelişen dejeneratif değişiklikler, spinal sinir 
köklerinin innerve ettiği paraspinal fasyada artmış bir duyarlılığa neden olabilir. Bu durum fasya üzerinde sinir uçlarının küçük uyaranlara bile artan hassasiyeti ve yanıt olarak nosiseptif sinyale yol açabilir (Langevin ve ark., 2006). Fasyal disfonksiyondan kaynaklanan artiküler kompresyon, eklem dejenerasyonu, ağrı, intervertebral disk ve faset eklem erozyonuna dönüşebilir ve bunlarla sınırlı kalmayıp kasları, vasküler sistemleri, sinir sistemlerini ve genel olarak bağ dokusununu etkileyebilir (Zeni ve ark., 2010). Fasyal disfonksiyon sonucu dorsal spinal sinirlerin irritasyonuna bağlı etkilenen segmentin etrafindaki paravertebral kaslarda tonus artış1, perfüzyon bozukluğu, komşu lokomotor yapılarda etkilenim, etkilenen segmente bağlı deride reaksiyon ve ilgili organlarda disfonksiyon yaratabilir (Acarkan ve ark., 2019). Faset eklem disfonksiyonu düşündüren görüntüleme bulguları arasında eklem boşluğunda daralma, eklem içi vakum fenomeni, osteofitler, sinoviyal kist oluşumu ve ligamentum flavum hipertrofisi bulunmaktadır (Langevin ve ark., 2007). Vazquez ve ark., C5C6 faset eklemi üzerinde basınçla ağrı ortaya çıkan mekanik boyun ağrılı bireylerde, tek bir seans kuru iğneleme sonrasında basınç ağrısı eşiğinde ve servikal eklem hareket açıklığında artış olduğunu bildirmişlerdir (Vazquez ve ark., 2014). Çalışmamızda elde ettiğimiz sonuçlara benzer başka bir çalışmada akupunktur iğnelerinin fasyadaki hücrelerin tepki verme şeklini değiștirebileceği gösterilmiş ve bu durum bağ dokusunun vücut boyunca sürekliliği, fasyanın mekanik rolü ve fibroblastların birbirleriyle yolakları ile iletişim kurma yeteneği, fasyanın buna benzer bir entegre işlevi olan vücut çapında mekanik duyarlı bir sinyal sistemi olarak hizmet edeceği anlamına gelmektedir (Filippiadis ve ark., 2016).

Faset eklem disfonksiyonunda herhangi bir aktif tedavi geliştirilmeden önce bu tür hususların dikkate alınması çok önemlidir. Fasyal terapatik yöntemlerin amacı tedavi edilen bölümün karş1lıklı sinerji ve biyomekanik karmaşıklığını göz önünde bulundurarak, yapıyı dengelemek için tedavi önerileri kullanmak olmalıdır (Wentzell, 2016).

\section{SONUÇ}

$\mathrm{Bu}$ sistematik derleme çalışması, faset eklem disfonksiyonlarında fasyal terapatik yaklaşımların ağrı, spazm ve EHA kısıtlılığ semptomlarında önemli oranda iyileşme gösterdiğini ortaya koymuştur. Fasyal tedavi yaklaşımları içerisinde kuru iğneleme, miyofasyal relaksasyon, fasyal manipülasyon, fasyal elektroakupunktur tekniklerinin daha fazla ön planda olduğu görülmüştür. Ancak bu çalışmaların etkinliğinin çıkarılabilmesi için daha fazla çalışmaya ihtiyaç duyulur. 
Journal of Integrative and Anatolian Medicine

Bütünlevici ve Anadolu Tıbbı Dergisi
Cilt/ Volume: 3 Sayı / Issue: 1 Yl/Year: 2021
Yaync1 / Publisher

Sağllk Bilimleri Üniversitesi

Universitv of Health Sciences Turkey

\section{Çıkar Çatışması}

Yazarlar, çıkar çatışması olmadığını beyan eder.

\section{KAYNAKLAR}

Acarkan T., Elmacıoğlu M.A., Nazlıkul H. (2019). Faset Eklem Sendromu ve Klinik Yansımaları, Journal Of Complementary Medicine, Regulation and Neural Therapy Volume 13, Number 1.

Ashton, I. K., Ashton, B. A., Gibson, S. J., Polak, J. M., Jaffray, D. C., Eisenstein, S. M. (1992). Morphological basis for back pain: the demonstration of nerve fibers and neuropeptides in the lumbar facet joint capsule but not in ligamentum flavum. Journal of orthopaedic research: official publication of the Orthopaedic Research Society, 10(1), $72-78$.

https://doi.org/10.1002/jor.1100100109

Barnes MF (1997). The basic science of myofascial release: morphologic changes in connective tissue. IN: Journal of Bodywork and Movement Therapies, 1(4): 231-238

Barop H. (2017): Textbook and Atlas of Neural Therapy: Diagnosis and Therapy with Local Anesthetics Thieme.

Bogduk N. (1997). Clinical anatomy of the lumbar spine and sacrum, 3rd edition. Edinburgh: Churchill Livingstone.

Bogduk N., Wilson A. S., Tynan W. (1982). The human lumbar dorsal rami. Journal of anatomy, 134(Pt 2), 383-397.

Brown D. (2020). A Review of the PubMed PICO Tool: Using Evidence-Based Practice in Health Education. Health Promot Pract. 21(4):496-498. doi:10.1177/1524839919893361

Falco F. J., Manchikanti L., Datta S., Sehgal N., Geffert S., Onyewu O., Singh V., Bryce D. A., Benyamin R. M., Simopoulos T. T., Vallejo R., Gupta S., Ward S. P., Hirsch J. A. (2012). An update of the systematic assessment of the diagnostic accuracy of lumbar facet joint nerve blocks. Pain physician, 15(6), E869-E907.
Filippiadis D. K., Kelekis A. (2016). A review of percutaneous techniques for low back pain and neuralgia: current trends in epidural infiltrations, intervertebral disk and facet joint therapies. The British journal of radiology, 89(1057), 20150357. https://doi.org/10.1259/bjr.20150357

Findley T, Chaudhry H, Stecco A, Roman M (2012). Fascia research: A narrative review. IN: Journal of Bodywork and Movement Therapies, 16(1): 67-75

Fujiwara A., Lim T. H., An H. S., Tanaka N., Jeon C. H., Andersson G. B., Haughton V. M. (2000). The effect of disc degeneration and facet joint osteoarthritis on the segmental flexibility of the lumbar spine. Spine, 25(23), 3036-3044. https://doi.org/10.1097/00007632-20001201000011

Glover J. R. (1977). Arthrography of the joints of the lumbar vertebral arches. The Orthopedic clinics of North America, 8(1), 37-42.

Hestbaek L., Kongsted A., Jensen T. S., Leboeuf-Yde, C. (2009). The clinical aspects of the acute facet syndrome: results from a structured discussion among European chiropractors. Chiropractic \& osteopathy, 17, 2. https://doi.org/10.1186/1746$\underline{1340-17-2}$

Hutton B., Salanti G., Caldwell D.M. (2015). The PRISMA extension statement for reporting of systematic reviews incorporating network metaanalyses of health care interventions: checklist and explanations. Ann Inter Med. 162(11):777-784.

Langevin H.M., Bouffard N.A., Churchill D.L., Badger G.J. (2007). Connective tissue fibroblast response to acupuncture: dose- dependent effect of bidirectional needle rotation. J Altern Complement Med 13, 355-360.

Langevin H.M., Sherman KJ. (2006). Pathophysiological model for chronic low back pain integrating connective tissue and nervous system mechanisms. Medical Hypotheses, vol. 68, no. 1, pp. 74-80.

Li W.D., Xu. H.Q., Qiu H.S. (2013). Tuina is superior to electroacupuncture in treating thoracic facet joint disorder. J. Acupunct. Tuina. Sci. 11, 375-379. https://doi.org/10.1007/s11726-013-0730-1

Maher C.G., Sherrington C., Herbert R.D., Moseley A.M., Elkins M. (2003). Reliability of the PEDro scale for rating quality of randomized controlled trials. Phys Ther. 83(8):713-721. 
Cilt/ Volume: 3 Sayı / Issue: 1 Yl/Year: 2021
Yaynca / Publisher

Sağllk Bilimleri Üniversitesi

Universitv of Health Sciences Turkey
Mejuto-Vázquez M. J., Salom-Moreno J., OrtegaSantiago R., Truyols-Domínguez S., Fernández-deLas-Peñas, C. (2014). Short-term changes in neck pain, widespread pressure pain sensitivity, and cervical range of motion after the application of trigger point dry needling in patients with acute mechanical neck pain: a randomized clinical trial. The Journal of orthopaedic and sports physical therapy, 44(4), $252-260$ https://doi.org/10.2519/jospt.2014.5108.

Paoletti S (2011). Fascia, anatomy, structures, techniques, special osteopathy, Urban and Fischer Verlag, Elsevier GmbH, München: 87ff., 103, 114, 117, 118f., 122.

Schleip R, Klingler W, Lehmann-Horn F (2008). Faszien besitzen eine der glatten Muskulatur vergleichbare Kontraktionsfähigkeit und können so die muskuloskelettale Mechanik beeinflussen IN: Osteopathische Medizin, 9(4): 19-21

Schwarzer A.C., Derby R., Aprill C.N. (1994). The value of the provocation response in lumbar zygapophyseal joint injections. The Clinical Journal of Pain. Dec;10(4):309-313. DOI: 10.1097/00002508-199412000-00011.

Shanmugam S., Mathias L. (2017). Immediate Effects of Paraspinal Dry Needling in Patients with Acute Facet Joint Lock Induced Wry Neck, Journal of Clinical and Diagnostic Research. Jun, Vol-11(6): YM01-YM03, DOI: 10.7860/JCDR/2017/26407.10079

Standring S. (2004). Gray's Anatomy: the Anatomical Basis of Clinical Practice. Edinburgh: Churchill Livingstone.

Stecco C, Porzionato A, Lancerotto L, Stecco A, Macchi V, Day JA, De Caro R (2008). Histological study of the deep fasciae of the limbs IN: Journal of Bodywork and Movement Therapies, 12(3): 225230.

Wentzell M. (2016). Fascial Dysfunction-Manual Therapy Approaches. The Journal of the Canadian Chiropractic Association, 60(1), 123.

Willard F.H. (2007). The muscular, ligamentous, and neural structure of the lumbosacrum and its relationship to low back pain. Movement, Stability \& Lumbopelvic Pain. 5-45. 10.1016/B978044310178-6.50003-7.

Vleeming A., Stoeckart R. (2007). The role of the pelvic girdle in coupling the spine and the legs: A clinicalanatomical perspective on pelvic stability. Movement, Stability \& Lumbopelvic Pain. 113137. 10.1016/B978-044310178-6.50010-4.

Ye T., Xue H.W., Wang Y., Liu L., Sun J.B. (2013). Zhongguo zhen jiu $=$ Chinese acupuncture \& moxibustion, 33(12), 1077-1080.

Zeni J. A., Rudolph K., Higginson J. S. (2010). Alterations in quadriceps and hamstrings coordination in persons with medial compartment knee osteoarthritis. Journal of electromyography and kinesiology : official journal of the International Society of Electrophysiological Kinesiology, 20(1), 148-154. https://doi.org/10.1016/j.jelekin.2008.12.003

Zhou W.C., Zhu J.F. (2016). Clinical observation on acupuncture at Jiaji (EX-B 2) points plus tuina in treating thoracic facet joint disorder. J Acupunct Tuina Sci, 14(2): 126-130. DOI: 10.1007/s11726016-0912-8 